Journal of Mathematics and Statistics 7 (4): 302-313, 2011

ISSN 1549-3644

(C) 2011 Science Publications

\title{
Markov Regime Switching Modelling and Analysis of Socially Responsible Investment Funds
}

\author{
${ }^{1}$ Eduardo D. Roca, ${ }^{1}$ Victor S.H. Wong and ${ }^{2}$ Gurudeo Anand Tularam \\ ${ }^{1}$ Department of Accounting, Finance and Economics, \\ ${ }^{2}$ School of Environment, Faculty of Science, Environment, \\ Engineering and Technology, Centre for Enviromental Futures, \\ Griffith University, Nathan, QLD 4111, Australia
}

\begin{abstract}
Problem statement: An increasing proportion of Australian superannuation funds are being placed in Socially Responsible Investments (SRI). Yet, there is no clarity in the literature as regards the risk and return characteristics of these investments and how their performance is affected by different states of the market and sector. Approach: We examine the sensitivity of Australian SRI Funds to movements of the US and Australian equity markets and SRI sectors under different market conditions through the application of Markov regime switching analysis. Results: We find that Australian SRI Funds are affected by movements in the US equity market and SRI sector during up and down market conditions. The Australian equity market also affects these funds but only during up market state. On the other hand, the Australian SRI sector does not have any significant effect on these funds. Conclusion: Australian SRI Funds are significantly driven by the US equity market and SRI sector and to a lesser extent, by the Australian equity market. The findings indicate that the returns of these funds are sensitive to market as well as sector movements and that Australian SRI Funds managers do not have market timing ability.
\end{abstract}

Key words: Superannuation funds, socially responsible investments, Markov regime switching, US equity market, Australian equity market

\section{INTRODUCTION}

Australia is the largest market in the Asian region and one of the world leaders in terms of Socially Responsible Investments (SRI) policy initiatives. Strong interest among investors and financial professionals has been driving the growth of the SRI market in Australia. From 2000-2006, SRI type managed portfolios grew from $\$ 325$ million to $\$ 11.98$ billion, representing an increase of $3,587 \%$, according to a report prepared by Corporate Monitor (2006) for the Ethical Investment Association of Australia. Employer superannuation funds accounted for $\$ 8.6$ billion out of the $\$ 11.98$ billion. The report noted the increasing number of superannuation funds providing SRI options. In 2005, there were 117 funds offering 317 SRI options and by 2006, this had increased to 122 funds with 350 SRI options.

Inspite of this increasing involvement of superannuation funds with SRI, the performance of this type of funds have not attracted attention from academic studies. At present, there is an amount of literature on superannuation funds which investigates different aspects of superannuation such as taxation (Bateman et al., 1993; Knox, 1992), annuities (Piggot et al., 2005), retirement timing (Kingston, 2000), disclosure (Gallery and Gallery, 2003), safety (Valentine, 2003), diversification (Diggle et al., 1999), performance (Bird et al., 1983; Robson, 1986; Sinclair, 1990; Hallahan, 1999; Sawicki and Ong, 2000; Prather et al., 2001; Drew and Stanford, 2010), returns, volatility and expenses (Coleman et al., 2003; Roca and Wong, 2008). Yet, none in the literature has focused primarily on the performance evaluation of Australian superannuation SRI funds and this study attempts to fill this gap in the superannuation literature.

An examination of this issue is important for two reasons. First, given the fast aging population of Australia, it is vital that superannuation funds perform well if they are to serve the retirement needs of the population. Australian superannuation funds have experienced increased growth over the last 15 years, increasing from $\$ 245$ billion in 1996 to $\$ 1.32$. However, in spite of this, studies show that Australian

Corresponding Author: Gurudeo Anand Tularam, School of Environment, Faculty of Science, Environment, Engineering and Technology, Centre for Enviromental Futures, Griffith University, Nathan, QLD 4111, Australia 


\section{J. Math. \& Stat., 7 (4): 302-313, 2011}

superannuation funds have underperformed over this period (Drew and Stanford, 2010; Gallagher, 2001; APRA, 2007) and these funds are under pressure to lift their performance. It is therefore important to find out the performance of Australian superannuation funds that have considered investments in SRI. Second, on one hand, there are claims that SRI can bring in better performance but on the other hand, they can also lead to lower returns; that is, it is not clear whether SRI will lead to improved or diminished performance. The current empirical evidence certainly does not provide any clear indication as shown later. This study then contributes to both the superannuation and SRI literatures.

SRI funds differ from conventional mutual funds in several ways. First, SRI funds employ SRI screens that restrict their investment opportunity set. The exclusion of companies based on social, environmental, corporate governance or ethical screens may thus reduce the diversification possibilities and negatively influence the performance of the SRI funds in comparison to conventional funds. However, the use of investment screens can also be regarded as an active selection strategy of firms with characteristics that are believed to yield better performance. The screens are used as filters to determine managerial competence, superior corporate governance and so on.

There are three dominant SRI screening practices; negative, positive and the best of sector screens. Negative or exclusionary SRI screens typically seek to exclude companies based on a set of social and environmental criteria and are most prevalent in screening out so called 'sin stocks' such as alcohol, tobacco, weapons, gambling, uranium and pornography. This is the most common method of screening with an obvious strength of being relatively easy to implement and administer. Positive screenings seek to promote and select companies based on a demonstrated ability and commitment to social and environmental issues. This screening is significantly broader in the range of companies, industries and countries that can now be included in an investors SRI portfolio. It allows fund managers and investors an increased selection of securities across a range of industries and countries that otherwise would not have been available. As such, positive screens increase one's investment opportunity set and returns potential whilst allowing for greater levels of adequate diversification. The best of sector approach does not preclude investment opportunities that would otherwise be excluded from those funds using traditional negative screens. This strategy is more inclusive SRI screen in that it favours those companies with the best social and environmental performance within each economic sector. The best of sector screening requires a rather detailed country, industry and company analysis to determine which firms lead their respective industries with regard to social, environmental and economic performance criteria. This screening approach is believed to be more consistent with risk management strategy than a set of ethical beliefs.

Based on a systematic analysis of the Australian superannuation SRI funds, acquired data sets will be analysed in order to address the following three interrelated issues in relation to the Australian SRI:

How sensitive are these funds to the movements in the Australian and US equity markets? SRI funds are supposed to be less sensitive to the market as their investors consider also non-market factors, i.e., utility arising from social causes. For instance, even if the market is down, they may less likely to discontinue their holdings of market sensitive assets since there are less available non-market sensitive assets that fulfill their non-financial objectives. Existing studies show that conventional superannuation funds are driven mainly by the US market and only to a limited extent by the Australian market (Roca and Wong, 2008; Tularam et al., 2010). Would SRI funds therefore be less driven by the US and Australian markets? This is an important issue if we are to understand better the systematic risk of these funds and therefore the attractiveness of SRI funds as vehicles for diversification.

How sensitive are these funds to movements of the SRI sector? This issue is important as this can provide further understanding not only of the systematic risks of SRI funds but also and more interestingly, whether there is an SRI factor in returns. At present, there is little agreement as to the direction of effect of SRI on returns. Most studies claim that SRI does not make a difference in return but other studies argue that it does. If SRI funds returns are found to be significantly affected by the SRI sector, then this can be taken as evidence pointing to the existence of an SRI factor.

Finally, do SRI funds exhibit any market timing ability? Existing studies have found that conventional superannuation funds do not have any market timing ability (Drew and Stanford, 2010; Roca and Wong, 2008). Would this be the case with regards to SRI funds?

The SRI literature is soemwhat limited but the subject is receiving an increasing amount of attention from the media, regulators, fund managers, institutional investors and other stakeholders. The existing empirical literature, do not unanimously agree on the nature of 
returns performance of SRI funds. Although many studies report that SRI perform equally as conventional funds, a significant number also show that SRI funds either over perform or underperform non-SRI funds. Diltz (1995); Guerard (1997) and Sauer (1997) concluded that there are no statistically significant differences between the returns of ethically screened and unscreened portfolios in the US. Using the single factor Jensen alpha models, Gregory et al. (1997) found no significant difference between the financial performance of ethical and non-ethical unit trusts in the US and UK, respectively. In a more recent paper, Bauer et al. (2005) used an international database containing 103 US, UK and German ethical mutual funds and noted also no significant difference in the risk-adjusted returns. Additionally, Kreander et al. (2005) did not find any significant difference between the returns of ethical and non-ethical funds in their study of 60 funds from the UK, Germany, Sweden and Netherlands.

Hamilton et al. (1993) and Statman (2000) compared the returns of ethical and regular US funds to each other and to both the S\&P 500 and the Domini Social Index (DSI). Their Jensen's alpha estimates suggested that the risk-adjusted returns of ethical mutual funds are not different from those of conventional funds. Goldreyer et al. (1999) used Jensen's alpha, Sharpe and Treynor ratios in their analysis and found that social screening does not affect the investment performance of ethical mutual funds in any systematic way. In support from outside the US and UK, Bauer et al. (2004) investigated 25 ethical funds using the Carhart (1997) four-factor return model on Australian data and found no significant difference in the risk-adjusted returns between ethical and nonethical funds.

In spite of these contrary findings, however, based on 463 SRI mutual funds in the US, UK, Continental Europe and Asia Pacific and using multi-factor asset pricing models, Renneboog et al. (2007) reported that although SRI funds in the US do not perform differently from their non-SRI counterparts, those in Europe and Asia do underperform strongly.

In the present study, the focus is on the analysis on the risk dimension-in particular, systematic risk of SRI for this aspect of SRI behavior has not been given due attention. This study will examine the sensitivity, in terms of extent, speed and duration of response, of Australian superannuation SRI funds to the movements of the equity market as a whole and to the SRI sector of the equity market taking into account different market regimes. The analysis will be in the context of the Australian and US markets as
Australian superannuation SRI funds mainly invest in these two markets.

This study will allow for the impact of market cycles as it is quite well established in the literature that financial markets are characterised by cycles or regimes such as down, normal and up states and that the relationship between risks and returns can differ under these different market conditions (Fabozzi and Francis, 1979; Chen, 1982; Wiggins, 1992; Schaller and Norden, 1997; Tu, 2004). Moreover, this study will determine the systematic risk or sensitivity of Australian superannuation SRI funds to the equity market and SRI sector movements under different states of the market. Such an analysis will provide more information concerning the effect of market movements on the SRI funds' returns. Furthermore, the sensitivity of the funds in each state of the market will be determined, this will in turn help provide an indication of the market timing ability. It is desirable that funds are most sensitive to the market when the market is up and least sensitive when the market is down. Thus, if SRI funds are found to be most highly affected by the market during the down market regime or least affected during the up market regime and then this can be interpreted as a sign of a lack of market timing ability.

The method used in studying market sensitivity of SRI superannuation funds will be based on the Markov regime switching analysis (Hamilton, 1989; Krolzig, 1997). One of the advantages of this approach is that it does not require prior specifications or dating of funds returns' regimes. Instead, regimes and their corresponding probabilities of occurrence are endogenously determined; thus allowing a more robust and informative analysis on the sensitivity of Australian superannuation SRI funds to market movements.

It is noted that the Australian superannuation SRI funds are mostly influenced by the US equity market and only to a small degree by the Australian equity market. This appears to be in line with the behavior of non-SRI funds reported in previous studies (Roca and Wong, 2008). It was noted that the Australian superannuation SRI funds do not have full success in timing the US market. On the other hand, they appeared to have more success with the Australian equity market given the exposure to the market. It was also noted that the Australian superannuation SRI funds are significantly influenced by the US, but not by the Australian SRI sector. Hence, the US is, but the Australian SRI sector is not, a source of systematic risk for the Australian superannuation SRI funds. The SRI 
sector (although it is only that of the US) affects Australian superannuation SRI funds. This could be taken as evidence that there is an SRI factor that impacts on returns.

The remaining sections explain the study in more detail concerning: material and methods used, the nature of the data analysed, findings and results of the present study including the VAR based impulse and response analysis and finally, a summary of the findings and conclusion is presented.

\section{MATERIALS AND METHODS}

In investigating the three interrelated issues stated earlier, a multi-index model in which Australian superannuation SRI funds returns are a function of the Australian and US equity markets, respectively is used. The model could be represented as Eq. 1:

$\mathrm{R}_{\mathrm{SRI}}=\alpha+\beta_{\text {Aus }} \mathrm{F}_{\text {Aus }}+\beta_{\mathrm{US}} \mathrm{F}_{\mathrm{US}}+\mathrm{e}$

Where:

$\begin{array}{ll}\mathrm{R}_{\mathrm{SRI}}= & \text { The returns of SRI funds } \\ \alpha & =\text { The intercept term } \\ \beta_{\mathrm{AUS}} \text { and } \beta_{\mathrm{US}}= & \text { Represent the sensitivity of SRI funds' } \\ & \text { returns to the movement of the } \\ & \text { Australian and US equity markets, } \\ & \text { respectively } \\ \mathrm{F}_{\mathrm{Aus}} \text { and } \mathrm{F}_{\mathrm{US}}= & \text { The returns on Australian and US } \\ & \text { markets, respectively } \\ \mathrm{e} & \text { The error term }\end{array}$

Each beta in Eq. 1 is allowed to vary or switch across different regimes. The betas will have a value for each regime. The Markov regime-switching model used is based on Krolzig (1997) that provides procedures to estimate these switching values of betas. The different regimes are endogenously identified by the model. The probability of occurrence (called regime probability) as well as the duration of each regime is moreover determined. In addition, the probability of switching to another regime is identified in the "transition probability" matrix; thus providing another indication of the volatility of a certain regime.

Each beta is decomposed to trace the co-movement of fund returns with each of the four markets. This is done by performing an impulse response analysis (Ehrmann et al., 2003). All analyses are performed within the context of a Vector Autoregression (VAR) framwork involving multivariate and simultaneous system of equations (Sims, 1980; Roca and Tularam, 2011). The VAR models will be considered in terms of changes in regime (Markov switching-VAR). In a general specification of an MS-VAR model; all parameters of the VAR are conditioned on the state $s_{t}$ of the Markov chain. Denoting the number of regimes by $\mathrm{m}$ and the number of lags by $\mathrm{p}$ and the observed time series vector $y_{t}$, the general form of the MS-VAR model (Eq. 2) is as follows:

$y_{t}=\left\{\begin{array}{c}\mathrm{v}_{1}+\mathrm{B}_{11} \mathrm{y}_{\mathrm{t}-1}+\ldots+\mathrm{B}_{\mathrm{p} 1} \mathrm{y}_{\mathrm{t}-\mathrm{p}}+\mathrm{A}_{1} \mathrm{u}_{\mathrm{t}} \text { if } \mathrm{s}_{\mathrm{t}}=1 \\ \vdots \\ \mathrm{v}_{\mathrm{m}}+\mathrm{B}_{1 \mathrm{~m}} \mathrm{y}_{\mathrm{t}-1}+\ldots+\mathrm{B}_{\mathrm{pm}} \mathrm{y}_{\mathrm{t}-\mathrm{p}}+\mathrm{A}_{\mathrm{m}} \mathrm{u}_{\mathrm{t}} \text { if } \mathrm{s}_{\mathrm{t}}=\mathrm{m}\end{array}\right.$

Where:

$\mathrm{y}=\left[\mathrm{y}_{1}, \mathrm{y}_{2}, \mathrm{y}_{3}\right]$

$\mathrm{y}_{1}=$ The returns on SRI funds

$\mathrm{y}_{2}=$ The returns on the Australian market

$\mathrm{y}_{3}=$ The returns on the US market

$\mathrm{V}=$ Represent the regime-dependent intercept term

$\mathrm{B}=$ The parameters shift functions

$\mathrm{s}_{\mathrm{t}}=$ Assumed to follow the discrete time and discrete state stochastic process of a hidden Markov chain;

$\mathrm{u}_{\mathrm{t}}=$ The vector of fundamental disturbances, is assumed to be uncorrelated at all leads and lags: $\mathrm{u}_{\mathrm{t}} \sim \mathrm{NID}\left(0, \mathrm{I}_{\mathrm{K}}\right) ; \mathrm{K}$ is the dimension of the coefficient matrix A (i.e., it describes the number of endogenous variable)

In order to determine the sensitivity of the Australian superannuation SRI funds to the Australian and US equity markets, i.e., the first issue, the DJTM indices are used as proxy for the market. This is called the "DJTM model". In order to determine the sensitivity of the Australian superannuation SRI funds to the Australian and US SRI sectors, i.e., the second issue, the DJSI as used as a proxy for the US and Australian markets - "DJSI model". These two models allows us to identify the extent by which the Australian and US equity markets and SRI sectors, respectively, are a source of systematic risk for Australian superannuation SRI funds.

For the purpose of finding the appropriate MS model, a number of diagnostic tests were conducted. The data is tested for unit roots (using the Augmented Dickey Fuller and Phillips-Perron tests) and hetersoskedasticity (based on the White Test). A test is conducted for the optimal number of regimes and number of lags for the model based on the Schwarz Information Criterion (SIC). Once the specific MS model is determined, the the procedures developed by Krolzig (1997) is then used to derive the following: (a) regime probabilities; (b) transition probabilities and (c) parameters or coefficients. Subsequently, an impulse response analysis is conducted by considering a moving average representation of the multiple VAR equation (VAR (m)) model where the constant terms may be 
ignored and written as: $\mathrm{Y}_{\mathrm{t}}=\Psi(\mathrm{L}) \mathrm{x}_{\mathrm{t}}$. If $\mathrm{E}\left(\mathrm{x}_{\mathrm{t}} \mathrm{x}_{\mathrm{t}}^{\prime}\right)=\Sigma \mathrm{x}$ such that shocks are contemporaneously correlated, then the impulse response function of $Y_{i}$ to a unit (one standard deviation) shock in $\mathrm{X}_{\mathrm{j}}$ is given by Eq. 3:

$\Psi_{\mathrm{ij}, \mathrm{h}}=\left(\sigma_{\mathrm{ii}}\right)^{-1 / 2}\left(\mathrm{e}_{\mathrm{j}}^{\prime} \sum \mathrm{xe}_{\mathrm{i}}\right)$

Where:

$\sigma_{\mathrm{ii}}=$ The $\mathrm{i}^{\text {th }}$ diagonal element of $\Sigma \mathrm{x}$

$e_{i}=A$ selection vector with the $i^{\text {th }}$ element equal to one and all other elements equal to zero, with $\mathrm{h}$ being the horizon (Roca and Tularam, 2011)

Data description: This study covers the period February 1996 to December 2005 due to the data availability, but more importantly, because of the richness of financial events within the period; such as, the Asian crisis and the surge in US bond prices in 1997, Russian crisis in 1998, Dotcom boom in 1999 followed by its collapse in 2000, September 11 attacks in 2001, Enron bankruptcy in late 2002 and the WorldCom and Adelphia bankruptcy in 2003. This study utilises weekly data in order to avoid noise, nonsynchronous trading and the day of the week effects associated with daily data. There are 570 weeks during the study period. Data is collected every Thursday of the week. In the case when Thursday data is not available, Friday data is used.

The Australian SRI funds data used in this study are obtained from Morningstar Research Pty Ltd (Morningstar), an independent measurement service and research house, which monitors the managed funds industry in Australia. All funds included in this analysis are represented in the database during the whole period of study, thereby, avoiding the survivorship bias problem created when funds, which do not survive for the full sample period, are absent from the database. As pointed out by Brown et al. (1992), leaving out dead funds leads to an overestimation of average performance. To limit possible survivorship bias, funds that were closed at any point during the sample perio were added back. Dead funds were included in the sample until they disappeared, after which the portfolios are re-weighted accordingly. Dead funds and funds that do not have sufficient data for two or more missing weeks are removed from the analysis (These include funds that are no longer traded, have only monthly data and with missing data for more than two weeks in the Morningstar database). After the process of filtering, 90 funds, out of the 130 funds, are left and these funds are then used in this study (The sample size of 90 funds is still above the recommended sample size of 88 funds based on a $90 \%$ confidence interval). As shown in Table 1, overall, the bulk of the portfolio of the 90 Australian superannuation SRI funds is in Australian equities (around 59\%) and international equities (around 20\%). The funds' investment in international equities is mainly in US stocks.

This study utilises the Dow Jones Sustainability Index (DJSI) and Dow Jones Total Market (DJTM) data for the Australian and the US markets. The DJSI is one of the world's first socially responsible indices and remains the first index seeking to track the performances of leading sustainability firms on a global basis. The DJSI is gaining momentum in the wider marketplace with many organisations actively seeking to invest according to sustainability criterion, with funds under management now exceeding $€ 3.6$ billion in 2006. There are now over 56 licenses issued to financial institutions in 14 countries across a range of active and passive funds, equity baskets, warrants and sustainability based investments. The DJSI provides a baseline product and an investment universe that identifies significant value in the concept of sustainability investing (DJSI, 2011).

The DJTM index covers $95 \%$ of the underlying market and incorporates a new global industry classification structure. It is based on float adjusted market capitalisation and firms included in the index are weighted according to their size and industry in the market. It comprises of 10 economic sectors indices and, historically, has held approximately 1,600 securities over 35 countries worldwide. The index can be used to serve as the basis for financial products, to benchmark the performance of investments and to act as a wealth measure that tracks the total value of a given market.

The DJSI derives its investment universe from the DJTM World with both indices employing the same methodology for calculating, reviewing and publishing their indices. The full integration of the two indexes enables a direct comparison of each index's characteristics, whilst allowing for a direct comparison of their relative risks and performance. The DJSI employs the best of sector approach in screening the companies. Its primary source of information comes from a company questionnaire with over 70 multiplechoice questions focusing on the economic, environmental and social dimensions with equal weighting in each of those dimensions. A senior member of the management from each DJSI rated company is then required to sign off on each questionnaire as a means of ensuring its accountability and accuracy. The remainder of the ratings information is subsequently sourced from either the specific request from company documentation or by direct dialogue between the analyst and company and finally through media and internet research. 


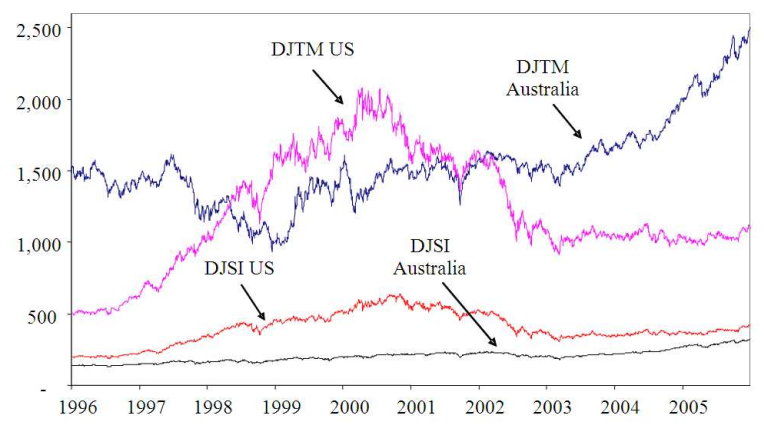

Fig. 1: Movements of the DJSI and DJTM of Australian and US markets during 1996-2005

Table 1: Portfolio composition of SRI funds

\begin{tabular}{lc}
\hline Asset classes & Percentage \\
\hline Australian equities & 59.18 \\
International equities & 19.71 \\
Australian fixed interest & 9.97 \\
Australian cash & 5.31 \\
Australia property & 2.22 \\
International fixed interest & 0.36 \\
International property & 0.21 \\
\hline
\end{tabular}

A major strength of DJSI is that it is one of the only SRI indexes that is fully and regularly audited and verified by independent auditors (Beloe et al., 2004).

The DJTM index consists of 1,606 companies in the US and 270 companies in Australia, out of which 58 US companies and 18 Australian companies are included in the DJSI index. Figure 1 shows the trend of the indexes used in this study. It can be clearly observed from the graph that the DJTM US market has more fluctuations or more volatility as compared to the DJTM Australian market. The fluctuations of the DJTM US market could be due to the financial distress events mentioned previously. The DJTM US market grew rapidly from 1997-2000 but fell in 2000-2003 and then grew again starting from 2003. On the other hand, the DJSI US and DJSI Australian markets grew steadily over the period studied although the DJSI US experienced significant volatility during its growth.

The weekly returns from SRI funds are calculated based on the exit price of the fund (which is net of management fees, excluding entry and exit loads) using the discrete returns formula of $R_{t}=\ln \left(\right.$ price $_{t} /$ price $\left._{t-1}\right)$ $\times 100$ (The continuous return formula is used as it is well-known to provide more accurate measure of return compared to the discrete formula (Brailsford et al., 2004). Other studies evaluating funds performance have used the same way of measuring returns (Sawicki and Ong, 2000; Benson and Faff, 2003; Bohl et al., 2009). Then, the funds' returns are combined or pooled by taking the weighted average of all the funds' returns.
The weight of each fund is based on its net asset value. For consistency, the returns for the Australian and the US markets are also calculated based on the same discrete returns formula. (Not the DJSI and DJTM datasets were obtained from DataStream).

\section{RESULTS AND DISCUSSION}

Diagnostic test results: To test for unit roots in each of the returns time series, the study performed the Augmented Dickey-Fuller (ADF) and Philips-Perron (PP) tests, as discussed previously. The null hypothesis of non-stationarity (unit root) and alternative hypothesis of stationarity (no unit root) are tested for each data series, in original form. The calculated $t$-statistics are presented in Table 2. The ADF and PP tests reject the null hypothesis of a unit root at 5\% level of significance. Both unit root tests suggest the funds' returns as well as those of the Australian and the US equity markets and SRI sectors are stationary. Consequently, the returns time series are used in the subsequent analysis without further differencing or testing for cointegration.

The next step in deciding the appropriate Markov switching model to use is to test for the existence of heteroskedasticity within the dataset, which is performed using the White (1980) test. The null hypothesis of no heteroskedasticity against heteroskedasticity of some unknown general form is tested. The results show a Chi-square 498.6686 corresponding to 300 degrees of freedom with a p-value of 0.0000 . Thus, the null hypothesis is rejected suggesting the data contained heteroskedasticity. Given these results, a variant model of the Markov switching ; namely, MSIAH (m) -VAR (p) model was applied.

The Schwarz Information Criterion (SIC) is used to determine the optimal number of regimes and lags to be used in the MS model. The SIC values for 2-4 regimes and 1-4 lags are shown in Table 3. The results show that the lowest SIC value corresponds to the Markov regime-switching model with 2 regimes and 1 lag for both the DJSI and DJTM models. Hence, this study adopts the Markov switching MSIAH (2)-VAR (1) model. Several other studies have used a Markov switching 2-regime model in capturing market cycles and forecasting future market condition (Schaller and Norden, 1997; Tu, 2004; Humala, 2005).

Regime and transition probabilities: Table 4 presents the corresponding probabilities and characteristics for each of the two regimes in the DJSI and DJTM models. Table 4 shows the funds stayed most of the time and also the for longest time in regime 1. 
Table 2: Unit root tests results

\begin{tabular}{lll}
\hline & Augmented Dickey-Fuller & Philips-Perron \\
\hline Funds' returns & -19.7872 & -19.7973 \\
DJSI Australian & -20.1631 & -20.1631 \\
DJSI US & -20.9632 & -20.8952 \\
DJTM Australian & -22.1493 & -22.1418 \\
DJTM US & -21.0049 & -20.9608 \\
\hline
\end{tabular}

Notes: Unit root tests based on model with constant and trend; Critical value at $5 \%$ level of significance: -3.45

Table 3: Schwarz Information Criterion Values for Markov Switching Models

\begin{tabular}{lccc}
\hline & 2 regimes & 3 regimes & 4 regimes \\
\hline DJSI model & & & \\
Lag 1 & $-17.3653^{*}$ & -17.3066 & -16.9748 \\
Lag 2 & -17.1826 & -17.0536 & -16.7802 \\
DJTM model & & & \\
Lag 1 & $-18.0017 *$ & -17.8692 & -17.6750 \\
Lag 2 & -17.8127 & -17.6063 & -17.3775 \\
\hline Notes: *: Lowest AIC value & &
\end{tabular}

Table 4: Probabilities and characteristics of each regime

\begin{tabular}{|c|c|c|c|c|c|}
\hline & Probability & $\begin{array}{l}\text { Average } \\
\text { Duration (\%) }\end{array}$ & $\begin{array}{l}\text { Number of } \\
\text { Observations }\end{array}$ & $\begin{array}{l}\text { Average } \\
\text { Returns }\end{array}$ & $\begin{array}{l}\text { Average } \\
\text { Volatility* }\end{array}$ \\
\hline \multicolumn{6}{|l|}{ DJSI model } \\
\hline Regime 1 & 70.19 & 41.2 weeks & 360.5 & 0.1347 & 0.0309 \\
\hline Regime 2 & 29.81 & 17.5 weeks & 156.5 & 0.1541 & 0.0153 \\
\hline \multicolumn{6}{|c|}{ DJTM model } \\
\hline Regime 1 & 76.79 & 16.1 weeks & 396.8 & 0.2210 & 0.0266 \\
\hline Regime 2 & 23.21 & 4.9 weeks & 120.2 & -0.1753 & 0.0245 \\
\hline
\end{tabular}

Notes: *: Average volatility is the average variance of funds' returns

Table 5: Probabilities of switching between regimes

\begin{tabular}{lcc}
\hline To: From: & Regime 1 (\%) & Regime 2 $(\%)$ \\
\hline DJSI model & & \\
Regime 1 & 97.57 & 2.43 \\
Regime 2 & 5.72 & 94.28 \\
DJTM model & & \\
Regime 1 & 93.78 & 6.22 \\
Regime 2 & 20.58 & 79.42 \\
\hline
\end{tabular}

The funds were in regime 1 for about $70 \%$ of the time and a period of about 41 weeks in the DJSI model and about $77 \%$ of the time and about 16 weeks in the DJTM model. Note, however, that regime 1 in the DJTM model is a regime characterised by higher returns $(0.2210$ for regime $1 \mathrm{Vs}-0.1753$ for regime 2 ) but it is a lower return regime in the DJSI model (0.1347 for regime 1 against 0.1541 for regime 2). This means that the SRI funds' relationship with the equity market (DJTM model) mostly occurred in a state of higher returns while its relationship with the SRI sector (DJSI model) mostly happened in a regime of lower returns. Note also that there is a larger variation in the returns between regimes in the DJTM model as compared to the DJSI model.

The switches between regimes are further explored in Table 5. The two numbers in a particular row show the probability of a regime shifting into regime 1 and 2, respectively. For example, in row 1, the first number $97.57 \%$, indicates the probability of regime 1 shifting into regime 1 , which means regime 1 staying in itself, while the second number, $2.43 \%$, shows the probability of regime 1 switching to regime 2 . For both the DJSI and DJTM models, it can be seen in Table 5 that there is a rather high probability of each regime staying in itself and thus only a small probability of switching to another regime. For the DJSI model, there is a $97.57 \%$ probability of regime 1 remaining in itself (and thus, only a $2.43 \%$ probability of switching to regime 2) and $94.28 \%$ probability of regime 2 staying in itself (and therefore, only 5.72\% probability of shifting to regime 1). For the DJTM model, the probability of staying in regime 1 is $93.78 \%$ (and therefore a $6.22 \%$ probability of switching to regime 2) and $79.42 \%$ in regime 2 (and hence, a $20.58 \%$ probability of shifting to regime 1 ). Thus, the regimes are fairly stable although they are to a lesser extent with respect the DJTM model. This means that the relationship of the SRI funds with the SRI sector is characterised by more regime stability as compared to the funds relationship with the equity market.

A graphical representation of the regime probabilities is presented in Figure 2. Inspection of the graph for the DJSI model shows that most of the time, the regimes are stable note in the relatively few spikes. The switches between regimes occurred during the periods 1996-1998 and 2000-2001. Additionally, the largest probability corresponds to regime 1 , which is characterised by longer duration (41 weeks) as presented in Table 4.

As for the DJTM model, Fig. 3 shows that there are more spikes or switches between regimes as compared to the DJSI model shown in Fig. 2. These spikes or switches are also of a relatively shorter duration. As noted in Table 4, the average durations for regimes 1 and 2 in the DJTM model are only 16.1 weeks and 4.9 weeks, respectively (as against 41.2 weeks and 17.5 weeks, respectively, for the DJSI model). Thus, Fig. 3 demonstrates that the regimes in the DJTM model are less stable compared to those in the DJSI model. The spikes in regime 2 (the lower returns regime) in the DJTM model corresponds to the periods where financial distress events occurred, such as the Asian crisis in 1997, Russian crisis in late 1998, Dotcom collapse in 2000, September 11 attacks in 2001, Enron bankruptcy in late 2002 and bankruptcies of WorldCom and Delphia in 2003 and also the London bombings in late 2005 . The events captured mostly occurred in the US, implying that the US market could have had a major impact on Australian SRI funds' returns. These events could explain the negative returns presented in Table 4. 

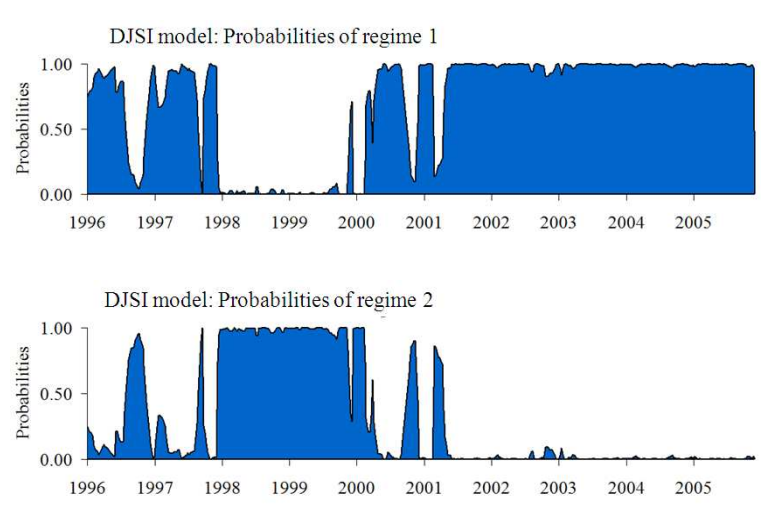

Fig. 2: Markov switching regime probabilities for DJSI Model
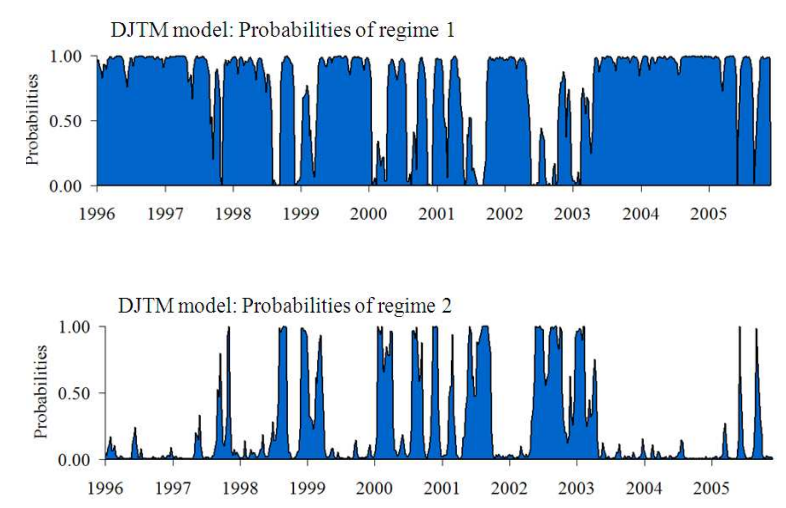

Fig. 3: Markov switching regime probabilities for DJTM Model

Table 6: Estimated coefficients for Markov switching model: Funds' Returns Vs Australian and US markets

\begin{tabular}{llc}
\hline Independent variables & Regime 1 & Regime 2 \\
\hline DJSI model & & \\
Australia & 0.0713 & 0.0367 \\
US & $0.1759 *$ & $0.2510 *$ \\
DJTM model & & \\
Australia & $0.2588 *$ & -0.2192 \\
US & $0.1522 *$ & $0.3360 *$ \\
\hline Notes: The model is based on &
\end{tabular}

Notes: The model is based on one lag.* 5\% significance level

Other studies that have employed the Markov switching model have shown the model is able to capture the periods containing market crashes. For instance, Tu (2004) analysed the investment decisions of 25 portfolios under up and down regimes during 1963-2002 and their model captured the events such as the oil price shocks in 1970s, the recession in the early 1980s, the October 1987 stock market crash, the 1997 Asian crisis and the recession in 2000. Humala (2005) applied the Markov switching model, which also identified the period of financial distress correctly.
Regime coefficients: The estimated parameters of the Markov switching model are presented in Table 6, which provide information on the sensitivity, in each regime, of the SRI funds' returns to the movement in the Australian and US, equity markets (DJTM model) and SRI sectors (DJSI model), respectively. As can be seen in Table 6, in the DJTM model, the US market has a statistically significant coefficient in all regimes. This means that the US equity market significantly affects Australian superannuation SRI funds' returns in all market conditions. On the other hand, the coefficient for the Australian equity market is only significant in one regime. These results imply that Australian SRI funds are mostly driven by the US equity market and only to a smaller extent by the Australian stock market. These results are similar to those of Roca and Wong (2008) with regards to Australian superannuation non-SRI funds. In terms of the DJSI model, again, the coefficients for the US market are significant in both regimes; however, the coefficients for the Australian market are not. This indicates that the US, but not the Australian, SRI sector, influences Australia superannuation SRI funds.

The results points to the US equity market as the dominant market affecting SRI funds' returns and this is consistent with the findings in the literature that the US stock market drives equity markets worldwide including Australia. For example, Roca (1999) found that the Australian equity market is linked with the US market in the short run. Ragunathan et al. (2000) also confirmed this when they found that the US market has a large impact on the Australian market. Sheng and Tu (2000) supported this claim by stating that US market has a strong relationship (both in short and long-term) with most of the Asian markets. Eun and Shin (1989) found that the US market is rapidly transmitting shocks to other markets in a recognisable manner, whereas no single foreign market can significantly explain the US market movements. They also found dynamic response patterns to be generally consistent with the notion of information efficient international stock market.

A closer look at Table 6 further reveals that the funds are sensitive to the US market in both regimes, even when the US equity market and the SRI sector are in a state of low returns i.e., regime 2 in the DTJM model and regime 1 in the DJSI model, respectively. In fact, the funds were even more sensitive to the market during regimes of low returns in the US equity market. In line with our expectation, these results could be interpreted as a lack of success in timing the US market. The funds, however, are exposed to the Australian equity market only during the state of high returns, i.e., regime 1 in the DJTM model. These results might indicate that if the funds were timing the market, then they had more success with the Australian equity market. 


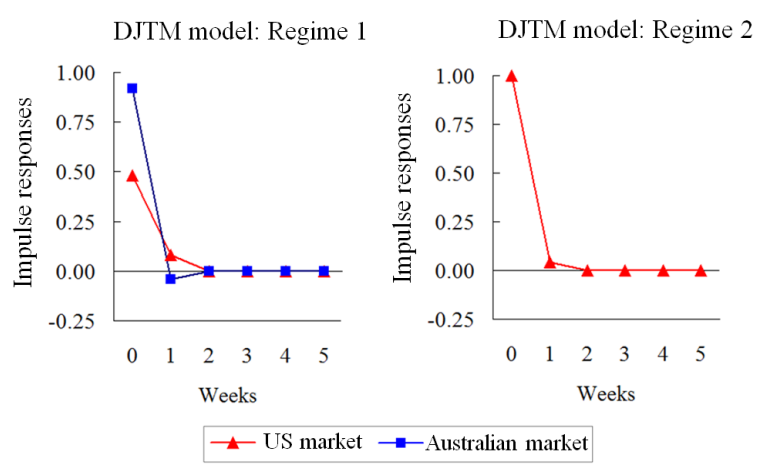

Fig. 4: Impulse Response of SRI funds returns to a shock in the DJTM Australia and US markets

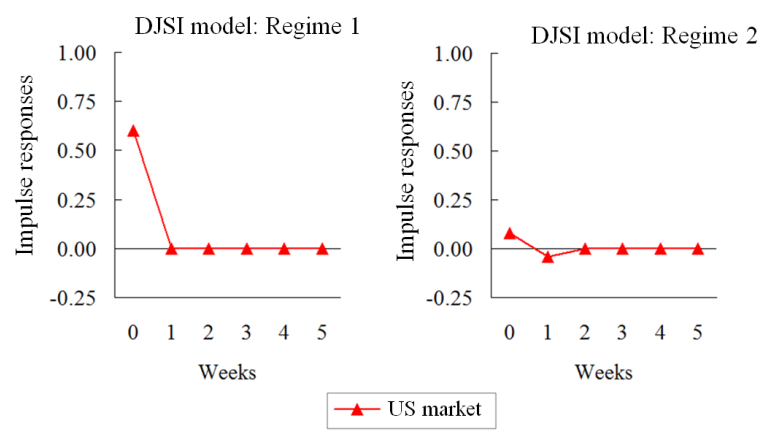

Fig. 5: Impulse response of funds returns to a shock in the DJSI US market

These findings are similar to those of Drew and Stanford (2010) and Roca and Wong (2008) with respect to Australian superannuation non-SRI funds. These results are also consistent with those of Fabozzi and Francis (1979) who found that fund managers did not reduce (increase) the funds' beta in down (up) market conditions to earn higher returns.

Impulse response analysis: Further investigation of the speed and duration of the superannuation funds' returns response to Australian and US markets movements is performed by decomposing the coefficients in each regime (shown in Table 6) through the use of impulse response analysis based on the Markov switching model. The impulse response analysis shows the expected change in the SRI funds' returns after a one standard deviation shock to the Australian and US markets under each regime on a weekly basis.

Figure 4 presents the impulse response of the funds' returns to the US equity market in regimes 1 and 2 and to the Australian equity market in regime 1. It can be seen that the funds respond to a shock in the US and Australian equity markets immediately, in a positive manner and then in a negative manner. They complete their response within a period of two weeks. Given that our study is based on weekly data, this response can be considered as efficient in line with Beechey et al. (2000); Bracker et al. (1999) and Roca (1999). Figure 4 further shows that the funds respond to the US equity market shock in a larger manner during regime 2 which means that the funds are more sensitive to the market during the down market regime and less sensitive during the up market state-a situation that is not desirable and therefore indicative of lack of market timing success. This further confirms the results presented in Table 6 .

The impulse response of the funds to the US SRI sector, presented in Fig. 5, show that the funds also respond quickly and briefly to the movement in the US SRI sector. They also respond immediately in a positive manner, followed by a negative response and complete their response in two-week's time during regime 2 and in an even shorter time-one week, during regime 1. The funds are therefore also efficient in responding to the US SRI sector movements (more efficient during regime 1). It can be noticed that the funds' immediate response during regime 1 is larger than that in regime 2 suggesting they are more sensitive to the market when the market is in a state of low returns than when the market is in a regime of high returns. This can interpreted as further evidence of a lack of market timing ability, if the funds were timing the market.

In summary, the Australian superannuation SRI funds just like their non-SRI counterparts, as reported by Roca and Wong (2008), also respond to the US and Australian equity markets and SRI sector almost immediately and briefly (within two weeks) and are therefore deemed efficient. They respond more strongly to the US market during periods of low returns and are less sensitive to the market during regimes of high returns. This may be also interpreted as evidence of a lack of market timing success.

\section{CONCLUSION}

This study investigated the sensitivity of Australian SRI funds to the Australian and US equity markets and SRI sectors. In particular, it examined the extent, speed and duration of response of the Australian SRI funds' returns to movements in the US and Australian equity markets; based on the DJTM indices and the SRI sectors using the DJSI. The investigation used the Markov regime-switching model methodology in which an impulse response analysis was also conducted. The study utilised weekly returns of 90 SRI funds, from the 
Morningstar database and the Australian and US markets based on the DJSI and DJTM indices (February 1996 to December 2005).

The overall results show that Australian superannuation SRI funds are mostly affected by movements in the US equity market and SRI sector and to a lesser extent, by the Australian equity market. These funds do not seem to be affected by the Australian SRI sector. With regards to the US market, the funds are also exposed, i.e., sensitive to the market, even when the market is down. This might indicate a lack of success on the part of these funds if they were indeed timing the US market. On the other hand, the funds are only exposed to the Australian equity market during periods of higher returns. If the funds were timing the Australian equity market, these results are an indication that they have more success with the Australian equity market. The impulse responses results also reveal that SRI funds immediately and quickly (within two weeks) respond to movements in markets. Given that the study is based on weekly data, this response may be considered efficient.

These findings are the same as those of Roca and Wong (2008) in relation to the non-SRI Australian superannuation funds. The results of the analysis with respect to the systematic risk dimension of funds' performance provide further evidence that SRI funds do not perform differently from non-SRI funds.

It may be noted that in relation to the exposure of SRI funds to the different regimes of the market, further studies could extend the Markov switching model by including ARCH effects (Schaller and Norden, 1997; Li and Lin, 2004) and also to allow for time-varying transition probabilities (Diebold et al., 1993). This is when the transition probabilities are allowed to vary with such information variables as the strength of the economy, deviations of fundamentals from actual values and other leading indicators of change. Interest rate, inflation rate, economic growth rate and business cycles could also be examined to determine how they may affect the sensitivity of superannuation funds. Studies could also explore the utility cost of SRI to the investors and its impact on the stock price issued by the firm (Beltratti, 2003).

\section{REFERENCES}

APRA, 2007. Quarterly Superannuation Performance.

Bateman, H., G. Kingston and J. Piggott, 1993. Taxes, retirement transfers and annuities. Econ. Record, 69: 274-284. DOI: $10.1111 / \mathrm{j} .1475-$ 4932.1993.tb02107.x
Bauer, R., K. Koedijk and R. Otten, 2005. International evidence on ethical mutual fund performance and investment style. J. Bank. Finance, 29: 1751-1767. DOI: 10.1016/j.jbankfin.2004.06.035

Bauer, R., R. Otten and A.T. Rad, 2004. Ethical investing in Australia: Is there a financial penalty? Pacific-Basin Finance J., 14: 33-48. DOI: 10.1016/j.pacfin.2004.12.004

Beechey, M., D. Gruen and J. Vickery, 2000. The Efficient Market Hypothesis: A Survey. 1st Edn., Reserve Bank of Australia, Economic Research Department, Sydney, NSW., pp: 30.

Beloe, S., J. Scherer and I. Knoepfel, 2004. Values for Money: Reviewing the Quality of SRI Research. 1st Edn., Sustain Ability, London, ISBN: 9781903168097, pp: 32.

Beltratti, A., 2003. Socially Responsible Investment in General Equilibrium. 1st Edn., Fondazione Eni Enrico Mattei, Milano, Italy, pp: 22.

Benson, K.L. and R.W. Faff, 2003. A performance analysis of Australian international equity trusts. J. Int. Financial Markets, Instit. Money, 13: 69-84. DOI: 10.1016/S1042-4431(02)00027-6

Bird, R., H. Chin and M. McCrae, 1983. The performance of Australian superannuation funds. Australian J. Manage., 8: 49-69. DOI: 10.1177/031289628300800104

Bohl, M.T., J. Brzeszczynski and B. Wilfling, 2009. Institutional investors and stock returns volatility: Empirical evidence from a natural experiment. J. Financial Stability, 5: 170-182. DOI: 10.1016/j.jfs.2008.02.003

Bracker, K., D.S. Docking and P.D. Koch, 1999. Economic determinants of evolution in international stock market integration. J. Empirical Finance, 6: 1-27. DOI: 10.1016/S09275398(98)00007-3

Brown, S.J., W. Goetzmann, R.G. Ibbotson and S.A. Ross, 1992. Survivorship bias in performance studies. Rev. Financ. Stud., 5: 553-580. DOI: 10.1093/rfs/5.4.553

Carhart, M.M., 1997. On persistence in mutual fund performance. J. Finance, 52: 57-82. DOI: $10.2307 / 2329556$

Chen, S.N., 1982. An examination of risk-return relationship in bull and bear markets using timevarying betas. J. Financ. Quantitative Anal., 17: 265-286. DOI: 10.2307/2330850

Coleman, A.D.F., N. Esho and M. Wong, 2003. The Investment Performance of Australian Superannuation Funds. 1st Edn., Australian Prudential Regulation Authority, Canberra, pp: 40. 
Corporate Monitor, 2006. Sustainable Responsible Investment in Australia -2006. A Benchmarking survey Conducted for the Ethical Investment Association of Australia.

Diebold, F.X., J.H. Lee and G.C. Weinbach, 1993. Regime Switching with Time-Varying Transition Probabilities. 1st Edn., Federal Reserve Bank of Philadelphia, Economic Research Division, Philadelphia, pp: 37.

Diggle, J., R. Brooks and J. Shannon, 1999. International diversification of the funds management industry. Applied Econ. Lett., 6: 663667. DOI: $10.1080 / 135048599352466$

Diltz, J.D., 1995. Does social screening affect portfolio performance? J. Invest., 4: 64-69.

DJSI, 2011. Dow Jones Sustainable Index (DJSI) Brochure.

Drew, M. and J. Stanford, 2010. Returns from investing in Australian equity superannuation funds, 19911999. Service Indus. J., 23: 12-24. DOI: $10.1080 / 02642060412331300982$

Ehrmann, M., M. Ellison and N. Valla, 2003. Regimedependent impulse response functions in a markovswitching vector autoregression model. Econ. Lett., 78: 295-299. DOI: 10.1016/S0165-1765(02)00256-2

Eun, C.S. and S. Shim, 1989. International transmission of stock market movements. J. Finance Quantitative Anal., 24: 241-56. DOI: $10.2307 / 2330774$

Fabozzi, F.J. and J.C. Francis, 1979. Mutual fund systematic risk for bull and bear markets: An empirical examination. J. Finance, 34: 1243-1250. DOI: $10.2307 / 2327248$

Gallery, G. and N. Gallery, 2003. Inadequacies and inconsistencies in superannuation fund financial disclosure: The need for a principles-based approach. Australian Econ. Rev., 36: 89-97. DOI: 10.1111/1467-8462.00269

Goldreyer, E.F., P. Ahmed and J.D. Diltz, 1999. The Performance of socially responsible mutual funds: incorporating sociopolitical information in portfolio selection. Managerial Finance, 25: 23-36. DOI: $10.1108 / 03074359910765830$

Gregory, A., J. Matatko and R. Luther, 1997. Ethical unit trust financial performance: Small company effects and fund size effects. J. Bus. Finance Account., 24: 705-725. DOI: 10.1111/14685957.00130

Guerard, J.B., 1997. Is there a cost to being socially responsible in investing? J. Forecast., 16: 475-490. DOI: 10.1002/(SICI)1099131X(199712)16:7<475::AID-FOR668>3.3.CO;2$\mathrm{O}$
Hallahan, T.A., 1999. The information content of portfolio performance history and persistence in fund performance: An examination of rollover funds. Account. Finance, 39: 255-274. DOI: 10.1111/1467-629X.00026

Hamilton, J.D., 1989. A new approach to the economic analysis of nonstationary time series and the business cycle. Econometrica, 57: 357-384. DOI: $10.2307 / 1912559$

Hamilton, S., H. Jo and M. Statman, 1993. Doing well while doing good? The investment performance of socially responsible mutual funds. Financ. Anal. J., 49: 62-66. DOI: 10.2469/faj.v49.n6.62

Humala, A., 2005. Interest rate pass-through and financial crises: Do switching regimes matter? The case of Argentina. Applied Finance Econ., 15: 7794. DOI: $10.1080 / 0960310042000297908$

Kingston, G.H., 2000. Efficient timing of retirement. Rev. Econ. Dynamics, 3: 831-840. DOI: 10.1006/redy.2000.0097

Knox, D.M., 1992. Taxing Superannuation in Australia: Cost and Benefits of the Alternatives. 1st Edn., Parkville, Vic., University of Melbourne, ISBN: 9780732504182, pp: 35.

Kreander, N., R.H. Gray, D.M. Power and C.D. Sinclair, 2005. Evaluating the performance of ethical and non-ethical funds: A matched pair analysis. J. Bus. Finance Accoun., 32: 1465-1493. DOI: 10.1111/j.0306-686X.2005.00636.x

Krolzig, H.M., 1997. Markov-Switching Vector Autoregressions: Modelling, Statistical Inference, and Application to Business Cycle Analysis. 1st Edn., Springer, Berlin, ISBN: 9783540630739, pp: 357.

Li, M.Y.L. and H.W.W. Lin, 2004. Estimating Valueat-risk via Markov switching ARCH models-An empirical study on stock index returns. Applied Econ. Lett., 11: 679-691. DOI: 10.1080/1350485042000236539

Piggot, J., A.V. Emiliano and B. Detzel, 2005. The simple analytics of a pooled annuity fund. J. Risk Insurance, 72: 497-520. DOI: 10.1111/j.15396975.2005.00134.x

Prather, L.J., K.L. Middleton and A.J. Cusack, 2001. Are $\mathrm{N}+1$ heads better than one? The timing and selectivity of Australian-managed investment funds. Pacific-Basin Finance J., 9: 379-400. DOI: 10.1016/S0927-538X(01)00021-X

Ragunathan, V., R.W. Faff and R.D. Brooks, 2000. Australian industry beta risk, the choice of market index and business cycles. Applied Financ. Econ., 10: 49-58. DOI: 10.1080/096031000331923 
Renneboog, L.D.R., J.R.T. Horst and C. Zhang, 2007. Socially responsible investments: Methodology, risk exposure and performance.

Robson, G.N., 1986. The investment performance of unit trusts and mutual funds in Australia for the period 1969-1978. Account. Finance, 26: 55-79. DOI: $10.1111 / \mathrm{j} .1467-629 X .1986 . t b 00080 . x$

Roca, E. and G.A. Tularam, 2011. Which way does water flow? An econometric analysis of the global price integration of water stocks. Applied Econ. J., 23: 1-10. DOI: 10.1080/00036846.2011.568403

Roca, E.D. and V.S.H. Wong, 2008. An analysis of the sensitivity of Australian superannuation funds to market movements: A Markov regime switching approach. Applied Financ. Econ., 18: 583-597. DOI: 10.1080/09603100601118292

Roca, E.D., 1999. Short-term and long-term price linkages between the equity markets of Australia and its major trading partners. Applied Financ. Econ., $\quad 9$ : $501-511 . \quad$ DOI: 10.1080/096031099332168

Sauer, D.A., 1997. The impact of social-responsibility screens on investment performance: Evidence from the Domini 400 social index and Domini equity mutual fund. Rev. Financ. Econ., 6: 137-149. DOI: 10.1016/S1058-3300(97)90002-1

Sawicki, J. and F. Ong, 2000. Evaluating managed fund performance using conditional measures: Australian evidence. Pacific-Basin Finance J., 8: 505-528. DOI: 10.1016/S0927-538X(00)00027-5

Schaller, H. and SV. Norden, 1997. Regime switching in stock market returns. Applied Financ. Econ., 7: 177-191. DOI: 10.1080/096031097333745
Sheng, H.C. and A.H. Tu, 2000. A study of cointegration and variance decomposition among national equity indices before and during the period of the Asian financial crisis. J. Multinational Financ. Manage, 10: 345-365. DOI: 10.1016/S1042-444X(00)00034-7

Sims, C.A., 1980. Macroeconomics and reality. Econometrica, 48: 1-48. DOI: 10.2307/1912017

Sinclair, N.A., 1990. Market timing ability of pooled superannuation funds January 1981 to December 1987. Accoun. Finance, 30: 51-65. DOI: 10.1111/j.1467-629X.1990.tb00112.X

Statman, M., 2000. Socially responsible mutual funds. Financ. Anal. J., 56: 30-39. DOI: 10.2469/faj.v56.n3.2358

Tu, J., 2004. Are Bull and Bear Markets Economically Important? 1st Edn., School of Business, Singapore Management University, Singapore, pp: 32.

Tularam, G.A., E.D. Roca and V.S.H. Wong, 2010. Investigation of Socially Responsible Investment Markets (SRI) Using Dynamic Conditional Correlation (DCC) method: Implications for diversification. J. Math. Stat., 6: 385-394. DOI: 10.3844/jmssp.2010.385.394

White, H., 1980. A heteroskedasticity-consistent covariance matrix estimator and a direct test for heteroskedasticity. Econometrica, 48: 817-838. DOI: $10.2307 / 1912934$

Wiggins, J.B., 1992. Betas in up and down markets. Financ. Rev., 27: 107-123. DOI: 10.1111/j.15406288.1992.tb01309.x 